\title{
(बR
}

\section{Successful Treatment of Valproic Acid Intoxication with Hemodialysis and L-Carnitine}

\author{
Hemodiyaliz ve L-Carnitine ile Valproik Asit Zehirlenmesinin Başarılı Tedavisi
}

\author{
Tuğba Atmaca Temrel', Seval İzdeş², Gülhan Kurtoğlu Çelik', Defne Altıntaş², Havva Şahin Kavaklı', Asliddin Ahmedali \\ 'Clinic of Emergency Medicine, AtatürkTraining and Research Hospital, Ankara, Turkey \\ ${ }^{2}$ Clinic of Intensive Care Unit, Atatürk Training and Research Hospital, Ankara, Turkey
}

\begin{abstract}
Valproic acid (VPA) is a conventional antiepileptic drug and, in parallel to its widespread prescription, it has been used in many cases of suicide attempts. VPA intoxication may cause electrolyte disturbances, hepatotoxicity, pancreatitis, bone marrow suppression, and brain edema. However, there is no specific antidote for treatment of VPA overdose. Case reports describe the efficacy of naloxone, L-carnitine and various extracorporeal elimination techniques in the treatment of VPA toxicity. We present the case of a 31 year old female with VPA intoxication who was successfully treated with hemodialysis and L-carnitine, and a review of the literature on the management of VPA overdose.
\end{abstract}

Keywords: Valproic acid, carnitine, hemodialysis Received:07.07.2012 Accepted: 19.07.2012

\section{ÖZET}

Valproik asit (VPA) geniş spektrumlu bir antiepileptiktir, bu nedenle yaygın olarak kullanılması özkıyım vakalarında sık karşılaşımasına yol açmıştır. VPA toksisitesinde elektrolit bozuklukları, hepatotoksisite, pankreatit, kemik iliği süpresyonu, beyin ödemi görülebilir. Ancak, VPA doz aşımı tedavisi için spesifik bir antidot yoktur. Olgu sunumları naloxone, L-karnitin ve çeşitli extrakorporeal eliminasyon tekniklerininVPA toksisitesinde etkinliğini açıklamaktadır. Biz 31 yaşında VPA intoksikasyonu bayan olgunun hemodiyaliz ve L karnitin ile başarılı tedavisini ve VPA toksisitesine yaklaşımın literatürünün gözden geçirilmesini burada sunuyoruz.

Anahtar Kelimeler: Valproik asit, karnitin, hemodiyaliz Geliş Tarihi: 07.07.2012 Kabul Tarihi: 19.07.2012

\section{Introduction}

Valproic acid (VPA) has been used as an antiepileptic drug for different types of seizures. In addition, it has been used to treat a wide spectrum of diseases ranging from bipolar and schizoaffective disorders, social phobia and neuropathic pain to migraine treatment and prophylaxis (1). However, in toxic doses severe complications such as brain edema, coma, hepatic failure, pancreatitis, bone marrow suppression, hyperammonemic encephalopathy may occur (2). Severe VPA intoxication, which is diagnosed based on VPA plasma concentration, may lead to death. After ingestion of enteric-coated, delayed-release preparations, serial concentrations should be measured to determine peak serum concentration which may be delayed $(2,3)$. There is no specific antidote for managing VPA intoxication. The treatment of VPA intoxication in the guidelines is mainly supportive (3). Overdose patients with acute VPA intoxication have been given levocarnitine (L-carnitine) in an attempt to increase VPA metabolism via beta oxidation and to reverse mitochondrial metabolic abnormalities (1). However, there is no precise dose of L-carnitine suggested for VPA intoxication. Extracorporeal methods to enhance VPA elimination such as hemodialysis, hemoperfusion and hemodiafiltration have been used although the effectiveness of these methods has not been fully characterized (4-6).

We report the case of a patient with a serious intoxication secondary to VPA overdose who was successfully treated with a combination of hemodialysis and L-carnitine.

\section{Case Report}

A 31-year-old woman, with a prior medical history of psychiatric disturbance coupled with a previous suicide attempt, was admitted to our emergency department (ED) after ingesting an unknown number of sustained-release formulation of VPA $500 \mathrm{mg}$. 
During the initial evaluation in the emergency department, she was agitated, disorientated and partially cooperative. Her blood pressure was 120/80 mmHg, heart rate was 72 beats/min, respiratory rate was 18 breaths/min and oxygen saturation was 98\%. Physical examination revealed a Glasgow coma score of $11\left(E_{3} V_{3} M_{5}\right)$. No pathology was detected in the other system examinations. Initial blood count, biochemical parameters and blood gas analysis were normal. VPA blood level was reported as above $150 \mu \mathrm{g} / \mathrm{mL}$, which is a toxic level. A nasogastric tube was inserted, and gastric lavage was performed but it was unrevealing. Then activated charcoal was given at a dose of $6 \times 50 \mathrm{gr}$ through the nasogastric tube. She was intubated and put on mechanical ventilation upon loss of consciousness during follow-up. Despite appropriate IV fluid loading at bolus doses, adequate blood pressure could not be maintained without vasoactive drug support. Dopamine and noradrenaline infusions were started. Then the patient was transferred to the intensive care unit (ICU). On the $3^{\text {rd }}$ hour of ED admission, emergent hemodialysis was started for elimination of VPA. Subsequently, intravenous L-carnitine infusion was started at a dose of $100 \mathrm{mg} / \mathrm{kg}$ during the first hour and continued at a dose of $50 \mathrm{mg} / \mathrm{kg}$ tid (each infusion lasting 8 hours). After the first hemodialysis session, the vasoactive drug infusions could gradually be stopped. The patient had regained consciousness after the dialysis but she was sedated with midazolam because she was agitated and uncooperative. On the second day in the ICU, blood gas values revealed metabolic acidosis with a $\mathrm{pH}$ of 7.29 (pH: $7.29, \mathrm{pO}_{2}$ : $88.7 \mathrm{mmHg}, \mathrm{pCO}_{2}: 34.3 \mathrm{mmHg}, \mathrm{HCO}_{3}: 17 \mathrm{mmol} /$ $\mathrm{dL}$, lactate: $62 \mathrm{mg} / \mathrm{dL}$ ). On the $3^{\text {rd }}$ day in the ICU, the sodium level was 161 and treatment for hypernatremia was planned. The level of ammonia was 2.29 (normal range: 0.1-0.8 mg/mL). VPA level was $88.79 \mu \mathrm{g} / \mathrm{mL}$ (within the therapeutic range). L-carnitine therapy was continued until the drug level fell to an undetectable range. The patient underwent daily hemodialysis sessions and received intravenous L-carnitine therapy. Blood count and biochemical analysis were performed daily. Liver enzymes did not become elevated. On the $4^{\text {th }}$ day in the ICU she was given 1 unit of erythrocytes and 4 units of thrombocytes because of a drop in the blood count results (Hb value: $7.1 \mathrm{~g} / \mathrm{dL}$ and thrombocyte count: 29.000/mL) She was not transfused again, and the complete blood count results were stable thereafter. She was extubated on the $5^{\text {th }}$ day of admission. On the $8^{\text {th }}$ day the patient was fully conscious and cooperative with complete orientation. Oral intake had started. She was discharged on the $10^{\text {th }}$ day from the ICU to be transferred to a psychiatric unit.

\section{Discussion}

We present a case of VPA intoxication with neurological involvement, hemodynamic instability, mild anemia and thrombocytopenia after VPA overdose. VPA may cause severe intoxication depending on the amount of intake. Therapeutic VPA concentrations are considered to be 50 to $100 \mu \mathrm{g} / \mathrm{mL}$ (3). Although serum concentrations do not correlate well with either seizure control or toxicity, adverse side effects increase as concentrations rise above $150 \mu \mathrm{g} / \mathrm{mL}$. Severe central nervous system complications may develop in patients who have a plasma level higher than $180 \mu \mathrm{g} / \mathrm{mL}$; coma and death may occur with levels above $800 \mu \mathrm{g} / \mathrm{mL}$ (3). Traditionally, treatment is mainly supportive $(1-3,7)$. Hemodialysis may be required in cases of severe renal fail- ure, treatment resistant metabolic acidosis and electrolyte disorders. However, there are recent reports of successful treatment of VPA intoxication with extracorporeal elimination of VPA (4-6). At therapeutic concentrations, $90 \%$ of VPA is bound to plasma proteins and removal by renal excretion or by hemodialysis is not possible (3). However, it is recognized that the percentage of protein bound drug molecules decrease at toxic doses while the percentage of free drug molecules increases $(5,6)$. With this information, extracorporeal elimination methods have been reported to be used with success. Charcoal hemoperfusion has been reported to be utilized in VPA overdose cases, yet it is a complicated method and is associated with adverse effects that may be serious (4). On the other hand, the pharmacokinetic properties of VPA (relatively low molecular weight, small volume of distribution and saturable protein-binding) suggest that hemodialysis alone could also be an effective therapy for acute VPA overdose $(4,6)$. In our case, the patient regained consciousness after hemodialysis and we believe hemodialysis contributed by increasing VPA clearance.

Valproic acid is an organic acid similar to fatty acids that is metabolized by the liver mainly via glucuronic acid conjugation, mitochondrial beta-oxidation and cytosolic omega-oxidation (1). Under normal conditions, cytosolic omega-oxidation pathway is a minor route, and although its products may be hepatotoxic they do not reach toxic levels (1). L-carnitine has an important role during the transportation of long chain fatty acids across the mitochondrial membrane and during their metabolism (1). However, during an overdose, VPA blocks the fatty acid beta-oxidation pathway in the mitochondria and auto-inhibits its own degradation. In addition, VPA is known to be associated with depleted carnitine stores during long term or high dose therapy, impairing mitochondrial beta-oxidation (1). As a result, minor pathways are activated leading to accumulation of hepatotoxic metabolites. Moreover, carnitine depletion impairs the urea cycle which results in high levels of ammonia that may cause hyperammonemic encephalopathy (1). Several authors suggest that intravenous L-carnitine administration could increase the beta-oxidation of VPA leading to a decrease in hepatotoxicity and a decrease in ammonia levels in patients with VPA overdose $(1,7)$.

There have been multiple reports on therapeutic use of L-carnitine for acute VPA toxicity as well as prophylactic supplementation during VPA treatment $(1,6)$. Some guidelines suggest prophylactic supplementation during treatment with VPA especially in the pediatric group, as VPA can impair endogenous production of L-carnitine (1). It is suggested that L-carnitine is effective and safe in patients with hyperammonemic encephalopathy and hepatotoxicity associated with VPA $(1,7)$.

Minville et al. (6) report a 36-year-old male patient with severe VPA poisoning who was treated with hemodialysis to reduce serum VPA levels, and with L-carnitine infusion as an empirical treatment for 4 days. Cerebral edema developed in the patient, despite the treatment, but the patient recovered without any sequelae. Overall, Lcarnitine seems effective and appears to be safe in the treatment of $\mathrm{VHE}$, despite the absence of randomized, controlled trials to support its use (7). 
After a systematic review of the published data for 657 patients with acute VPA overdose, Perrott et al. (8) recommended an initial IV loading dose of L-carnitine $100 \mathrm{mg} / \mathrm{kg}$ (up to $3 \mathrm{~g}$ ) over an hour and a continuous IV infusion of L-carnitine $50 \mathrm{mg} / \mathrm{kg}$ tid until the patient recovers clinically or side effects occur due L-carnitine, for patients with impaired consciousness. They reported that all patients survived and no adverse effects related to L-carnitine were observed.

In our case we used the dosage suggested by Perrott and colleagues, and continued L-carnitine infusion until clinical improvement was observed and we did not observe any side effects. The CNS symptoms that were present on admission, accompanied by high ammonia levels, were probably related to VPA induced hyperammonemic encephalopathy, and the patient recovered without any sequelae after a combination of hemodialysis and L-carnitine treatment.

\section{Conclusion}

The presented case of VPA intoxication was treated with hemodialysis and L-carnitine; hepatotoxicity did not develop and the patient recovered from a toxic dose of VPA. We suggest hemodialysis and L-carnitine supplementation should be considered in the management of serious VPA intoxications involving adults, when complicated with hemodynamic and neurological instability, in order to reduce morbidity and mortality.

\section{Conflict of interest}

No conflict of interest was declared by the authors.

\section{References}

1. Lheureux PE, Hantson P. Carnitine in the treatment of valproic acidinduced toxicity. Clin Toxicol (Phila) 2009; 47: 101-11. [CrossRef]

2. Mirski M. Anticonvulsants in the intensive care unit. In Textbook of Critical Care. 5th Edition. Ed. Fink MP, Abraham E, Vincent JL, Kochanek P; Elsevier Saunders, 2005. p.1607-19.

3. Aaron CK. Anticonvulsants. In Irwin and Rippe's Intensive Care Medicine.(5th Edition). Eds Irwin RS, Rippe JM. Lippincott Williams and Wilkins; 2003.p.1383-92.

4. Van der Wouden EA, Dekkers A, Kruis HM, van Geijlswijk IM, Tjan DH, Feith GW. Extracorporeal elimination in acute valproate intoxication. BMJ Case Rep 2009.

5. Jung J, Eo E, Ahn KO. A case of hemoperfusion and L-carnitine management in valproic acid overdose.Am J Emerg Med 2008; 26: 388.

6. Minville V, Roche Tissot C, Samii K. Haemodialysis, L-carnitine therapy and valproic acid overdose. Ann Fr Anesth Reanim 2004; 23: 357-60. [CrossRef]

7. Mock CM, Schwetschenau KH. Levocarnitine for valproic-acid-induced hyperammonemic encephalopathy. Am J Health Syst Pharm 2012; 69: 35-9. [CrossRef]

8. Perrott J, Murphy NG, Zed PJ. L-carnitine for acute valproic acid overdose: a systematic review of published cases. Ann Pharmacother 2010; 44: 1287-93. [CrossRef] 